\title{
KARAKTERISTIK FENOTIPE HIBRIDA HUNA BIRU (Cherax albertisii) DENGAN HUNA CAPITMERAH (Cherax quadricarinatus)
}

\author{
Irin Iriana Kusmini"), Komar Sumantadinata"), Estu Nugroho"), dan Alimuddin ${ }^{* *}$ \\ *) Balai Riset Perikanan Budidaya Air Tawar \\ Jl. Sempur Raya No.1, Bogor 16154 \\ E-mail: iriniriana@gmail.com \\ **) Departemen Budidaya Perairan_FPIK, Institut Pertanian Bogor \\ Jl. Lingkar Akademik, Kampus IPB Darmaga, Bogor 16680
}

(Naskah diterima: 8 Februari 2010; Disetujui publikasi: 27 April 2010)

\begin{abstract}
ABSTRAK
Lobster air tawar (huna) adalah spesies endemik dan merupakan komoditas perikanan spesifik lokal Papua dan Australia, yang termasuk famili Parastacidae dan genus Cherax. Secara morfologi ada persamaan bentuk dan warna antara huna biru dengan capitmerah. Diduga terjadi inbreeding yang menyebabkan produksi huna capitmerah mulai menurun. Hibridisasi antar huna bertujuan untuk meningkatkan keragaman genetiknya sehingga diperoleh kualitas benih huna yang lebih baik dalam hal pertumbuhan dan sintasan. Hasil penelitian menunjukkan bahwa pertumbuhan turunan hibrida antara huna capitmerah dengan huna biru sampai 4 bulan relatif sama dengan non hibrida, pada umur 5 bulan pertumbuhan hibrida mulai terlihat lebih cepat dibandingkan dengan yang non hibrida. Hibridisasi jantan huna biru dengan betina huna capit merah (AR) menghasilkan hibrida dengan efek heterosis $25 \%$ pada kenaikan bobot badannya. Hibridisasi jantan huna capitmerah dengan betina huna biru (RA) menghasilkan nilai sintasan yang lebih baik dibandingkan dengan AR.
\end{abstract}

KATA KUNCI: huna biru (Cherax albertisii), huna capitmerah (Cherax quadricarinatus), fenotipe, hibridisasi

ABSTRACT: Phenotype characteristics of blue crayfish (Cherax albertisii) and red claw crayfish (Cherax quadricarinatus). By: Irin Iriana kusmini, Komar Sumantadinata, Estu Nugroho, and Alimuddin

Freshwater crayfish is a species endemic to Papua and Australia and one of specific fisheries commodities in these regions. This species is classified in the family of Parastacidae and genus of Cherax. Morphologically, blue and red claw crayfish have a similarity in body shape and color. Because of inbreeding pressure, the production of red claw has been declining. Hybridization between blue and red claw crayfish was aimed to increase genetic variation of crayfish in order to produce better quality of fingerlings in terms of growth and survival rate. The result showed that at four monthold, the growth of blue crayfish and red claw hybrid was similar to that of the non hybrid crayfish. After reaching five month-old, the hybrid grew faster than the non hybrid. Hybridization of male blue crayfish with female red claw crayfish (AR) produced hybrid that had 25\% heterosis effect on the increase of body weight. Hybridization between female blue crayfish and male red claw crayfish (RA) produced higher survival rate than the mix between male blue crayfish and female red claw crayfish (AR).

KEYWORDS: redclaw, blue crayfish, phenotype, hybrid 


\section{PENDAHULUAN}

Huna biru merupakan spesies endemik Irian Barat. Penyebarannya sangat dipengaruhi oleh jenis dan kondisi lingkungan serta ketinggian suatu daerah. Biasanya dapat ditemukan pada lokasi dengan ketinggian 30 meter di atas permukaan air laut.

Huna capitmerah berasal dari wilayah tropis Australia bagian utara namun sekarang ini sudah banyak dibudidayakan di Indonesia. Huna capitmerah termasuk satu genus dengan huna biru. Kedua spesies ini memiliki banyak kesamaan dalam morfologi kecuali pada bentuk dan warna capitnya. Disebut huna capitmerah karena dikedua ujung capitnya terdapat warna merah.

Pada tahun 2003 produksi huna capitmerah di Indonesia berkembang cukup pesat namun kemudian mengalami penurunan pada tahun 2007. Ketersediaan benih yang bermutu unggul, baik dari segi kualitas, kuantitas, dan kontinuitas, seringkali merupakan masalah yang dihadapi dalam budidaya ikan, termasuk budidaya huna. Umumnya pada tahapan awal budidaya yang sedang berkembang seperti huna, produksi akan cukup bagus namun lambat laun produksinya akan menurun pada generasi berikutnya sebagai akibat penurunan mutu benih dan induk yang ada hubungannya dengan penurunan keragaman genetik.

Penurunan produksi ini dapat disebabkan oleh pengelolaan induk dalam budidaya dan terjadi silang dalam (inbreeding) yang dapat menyebabkan terjadinya penurunan keraga- man genetik, salah satu program untuk meningkatkan keragaman genetik adalah dengan hibridisasi, sehingga untuk meningkatkan keragaman benih sebar huna capitmerah perlu penelitian hibrid antara huna capitmerah dengan huna biru. Hibridisasi dapat meningkatkan keragaman genetik, yaitu karakter-karakter dari tetuanya akan saling bergabung menghasilkan turunan yang tumbuh cepat, terkadang steril (triploid), tahan terhadap penyakit dan tahan terhadap perubahan lingkungan yang ekstrim (Hickling, 1968).

Pengukuran keragaman genetik dari hibridisasi dapat dilakukan melalui karakter fenotipe. Karakter fenotipe dapat dilihat dari morfologi dan pertumbuhan keturunannya yaitu pengukuran kuantitatif hybrid vigour yang disebut heterosis, didefinisikan sebagai persentase peningkatan performa dari hasil hibridisasi di atas rataan tetuanya. Hibridisasi antar huna bertujuan untuk meningkatkan keragaman genetiknya sehingga diperoleh kualitas benih huna yang lebih baik dalam hal pertumbuhan dan sintasan. Selain itu, juga untuk mengetahui perbedaan morfologi dan rasio jenis kelamin benih huna hibrida.

\section{BAHAN DAN METODE}

\section{Rancangan Perlakuan}

Induk huna biru dengan huna capitmerah, dipijahkan secara alami di akuarium ukuran 50 $\mathrm{cm} \times 50 \mathrm{~cm} \times 40 \mathrm{~cm}$, dengan sistem resirkulasi. Terdapat 4 perlakuan pemijahan yaitu:

1. Jantan huna biru $x$ betina huna biru (AA);

Tabel 1. Skema perlakuan pemijahan huna biru dengan huna capitmerah

Table 1. Spawning treatment scheme of blue and redclaw crayfish

\begin{tabular}{|c|c|c|}
\hline $\begin{array}{l}\text { Betina } \\
\text { Female }\end{array}$ Mantan & $\begin{array}{l}\text { Huna biru } \\
\text { Blue crayfish } \\
\text { (A) }\end{array}$ & $\begin{array}{c}\text { Huna capit merah } \\
\text { Redclaw } \\
\text { (R) }\end{array}$ \\
\hline Huna biru & AA & AR \\
\hline Blue crayfish & 1 jantan : 3 betina & 1 jantan : 3 betina \\
\hline (A) & 1 male : 3 female & 1 male : 3 female \\
\hline Huna c apitmerah & RA & RR \\
\hline Redclaw & 1 jantan : 3 betina & 1 jantan : 3 betina \\
\hline (R) & 1 male : 3 female & 1 male: 3 female \\
\hline
\end{tabular}


2. Jantan huna biru $x$ betina huna capitmerah (AR);

3. Jantan huna capitmerah $x$ betina huna capitmerah (RR);

4. Jantan huna capitmerah $x$ betina huna biru (RA);

Ulangan dalam pemijahan ini sebanyak 3 ulangan yaitu jumlah indukan betina yang dipijahkan dalam masing-masing pemijahan 1 jantan : 3 betina.

Perlakuan pemijahan sebagai berikut:

\section{Pemijahan dan Pembenihan}

Percobaan pemijahan dilakukan sistem resirkulasi, yang dilengkapi dengan kerikil batu kapur $\left(\mathrm{CaCO}_{3}\right)$ sebagai sumber kalsium. Tiga induk betina yang dapat menghasilkan benih (sebagai ulangan). Masing-masing perlakuan diberi potongan pipa PVC, yang berfungsi sebagai shelter untuk berlindung.

Pakan yang diberikan pagi hari berupa pelet udang dengan kadar protein $42 \%$ dan pada sore hari cacing tanah sebanyak 3\% dari bobot massa per hari.

Untuk masing-masing perlakuan:

- Induk-induk yang bertelur diamati setiap sepuluh hari sekali

- Induk-induk yang bertelur dipisahkan dalam akuarium penetasan secara terpisah untuk masing-masing perlakuan dan ulangan

- Masa inkubasi biasanya 1,5-2 bulan, indukinduk yang telah menghasilkan benih diukur bobotnya, dikembalikan ke bak akuarium pemijahan

- Benih yang diperoleh dihitung, ditimbang bobot per ekor, dan diberi pakan pelet udang sebanyak $3 \%$ dari bobot biomassa per hari.

\section{Pembesaran Benih Huna di Bak Tembok}

Setelah telur menetas benih yang diperoleh dipelihara di bak tembok ukuran 2 $\mathrm{m} \times 2,5 \mathrm{~m} \times 0,8 \mathrm{~m}$ dengan sistem air mengalir, pembesaran secara terpisah sesuai dengan masing-masing perlakuan dan ulangan. Kepadatan benih 80 ekor/bak tembok.

Pakan diberikan setiap hari sebanyak 3\%$10 \%$ dari bobot biomassa berupa pelet udang. Pengamatan pertumbuhan dilakukan setiap 1 bulan sekali, dengan cara sampling $25 \%$ atau
20 ekor benih masing-masing perlakuan dan ulangan, benih ditimbang bobotnya per ekor dan diamati perbedaan morfologis dengan cara mengukur panjang total, panjang standar, panjang kepala $(\mathrm{cm})$. Sedangkan panjang capit dan lebar capit (cm) diukur setelah berumur 5 bulan. Setiap tolok ukur kemudian dibandingkan terhadap persilangan lainnya dan terhadap turunan masing-masing induknya. Pemeliharaan untuk mengamati bobot rataan dan perbedaan morfologis serta sintasan dilakukan selama 9 bulan.

Rasio jenis kelamin yang dihasilkan dari persilangan diamati setelah benih berumur 5 bulan (Lampiran 1), dihitung jumlah jantan dan betina yang dihasilkan dari masing-masing persilangan.

\section{Analisis Data}

1. Pertumbuhan bobot individu Cherax selama percobaan, dinyatakan dalam pertambahan bobot rata-rata (g). Rata-rata bobot individu yang diperoleh dihitung dengan rumus sebagai berikut:

$$
X=\frac{\Sigma X 1+\Sigma X 2+\Sigma X 3+\Sigma X 4+\ldots+\Sigma X n}{n}
$$

di mana:

$X$ = Rata-rata bobot individu (Average of individual body weight)

$\mathrm{n}$ = Jumlah individu sampling (Number of sampled individual)

2. Sintasan

$$
\mathrm{S}=\mathrm{Nt} / \mathrm{No} \times 100 \% \quad \text { (Effendie, 1979) }
$$

di mana:

$$
\mathrm{S}=\text { Sintasan (Survival rate) }
$$

$\mathrm{Nt}=$ Jumlah Cherax yang hidup pada akhir penelitian (ekor) (Survived crayfish at the end of the research)

No = Jumlah Cherax yang hidup pada awal penelitian (ekor) (Initial number of crayfish)

Pertambahan bobot dan sintasan serta perbedaan morfologis dari masing-masing perlakuan pemijahan, dianalisis menggunakan ANOVA dengan software SPSS 11,5.

3. Nilai heterosis dihitung dari data pertumbuhan yang diperoleh menggunakan rumus (Tave, 1993). Misalkan heterosis antara huna biru (A) $\mathrm{X}$ huna capitmerah (R) 


$$
H_{A R}=\frac{A R-(A A+R R): 2}{(A A+R R): 2} \times 100 \%
$$

di mana:

$\mathrm{H}_{\mathrm{AR}}=$ Heterosis antara huna biru $\mathrm{x}$ huna capitmerah (Heterosis between blue $x$ redclaw crayfish)

$\mathrm{AR}=$ Parameter terukur hasil perkawinan jantan huna biru x betina huna capitmerah (Measured parameters in crossbreeding of male blue $x$ female redclaw crayfish)

RA = Parameter terukur hasil perkawinan jantan huna capitmerah $x$ betina huna biru (Measured parameters in crossbreeding of male redclaw $x$ female blue crayfish)

$\mathrm{AA}=$ Parameter terukur hasil perkawinan jantan huna biru $x$ betina huna biru (Measured parameters in crossbreeding of male $x$ female blue crayfish)

$\mathrm{RR}=$ Parameter terukur hasil perkawinan jantan huna capitmerah $\mathrm{x}$ betina huna capitmerah (Measured parameters in crossbreeding of male $x$ female redclaw crayfish)

\section{HASIL DAN BAHASAN}

\section{Pertumbuhan Turunan Hibrid Huna}

Rata-rata bobot badan pada umur 5 bulan perlakuan AR \& RA lebih tinggi daripada RR \& AA, antara perlakuan AR \& RA berbeda nyata dengan RR \& AA. Sedangkan pada umur 9 bulan rata-rata bobot badan AR paling tinggi di antara perlakuan namun tidak berbeda nyata dengan RA $(P>0,05)$. Pertumbuhan turunan hibrida antara huna capitmerah dengan huna biru sampai umur 4 bulan relatif sama, pada umur 5 bulan mulai tumbuh lebih cepat daripada yang non hibrida (Gambar 1). Hal ini diduga variasi dominan untuk pertumbuhan huna baru terlihat mulai umur 5 bulan.

\section{Efek Heterosis}

Nilai efek heterosis huna AR dan RA pada umur 5 bulan dan 9 bulan umumnya positif, kecuali lebar capit pada RA memiliki nilai heterosis negatif pada umur 5 bulan dan AR pada umur 9 bulan (Tabel 2).

Nilai efek heterosis hibrida jantan huna biru dengan betina huna capitmerah (AR) baik pada umur 5 bulan maupun 9 bulan menghasilkan efek heterosis sekitar $25 \%$ pada pertumbuhan bobot badannya sedangkan betina capitmerah positif untuk bobot badan. Menurut Tave (1993), hibridisasi dapat memperbaiki produktivitas karena eksploitasi vd (variasi dominan). Variasi dominan adalah keragaman genetik yang dihasilkan oleh interaksi masingmasing alel pada lokus atau kombinasi alel berbeda pada suatu lokus (Beaumont \& Hoare, 2003). Nilai efek heterosis tinggi ditunjang juga dengan hasil heterozigositas hibrida (AR \& RA) yang lebih tinggi daripada non hibrida (AA \& RR). Hibridisasi bermaksud menggabungkan karakter-karakter dari tetuanya yang akan dimunculkan pada turunan sebagai efek heterosis atau sifat unggul dari hasil hibridisasi (Falconer, 1996). Persilangan antara betina Cherax roduntus $x$ jantan Cherax albitus menghasilkan turunan jantan semua, dengan pertumbuhan 4,8 kali lebih cepat setelah dipelihara selama 424 hari (Lawrence, 2005). Menurut Ryman \& Utter (1987), benih hibrid mengekspresikan suatu kombinasi karakteristik yang terletak di antara kedua spesies induknya.

Panjang badan dan kepala pada umur 9 bulan hibrid lebih tinggi daripada non hibrid. Sedangkan nilai heterosisnya baik pada umur 5 bulan maupun 9 bulan panjang badan, perlakuan AR lebih tinggi daripada RA. Hal ini menunjukkan adanya kontribusi gen dari induk betina huna capitmerah sehingga $A R$ mempunyai nilai heterosis yang lebih tinggi daripada RA. Menurut Tim Cherax (2006), ukuran badan huna capitmerah lebih besar dibandingkan dengan huna biru. Sedangkan nilai heterosis panjang kepala pada umur 5 bulan AR lebih tinggi dari RA dan sebaliknya pada umur 9 bulan. Menurut Falconer (1996), hibridisasi bermaksud menggabungkan karakter-karakter dari tetuanya yang akan dimunculkan pada turunan sebagai efek heterosis atau sifat unggul. Nilai heterosis untuk panjang kepala pada umur 5 bulan AR lebih tinggi daripada RA, sebaliknya pada umur 9 bulan nilai heterosis panjang kepala RA lebih tinggi daripada AR. Nilai heterosis panjang capit pada umur 5 bulan AR jauh lebih tinggi daripada RA, sebaliknya pada umur 9 bulan RA jauh lebih tinggi daripada AR. Demikian juga untuk lebar capit RA memiliki nilai heterosis negatif pada umur 5 bulan dan AR pada umur 9 bulan. Nilai heterosis untuk panjang capit baik pada umur 5 bulan maupun 9 bulan menunjukkan nilai positif, sedangkan untuk lebar capit ada yang menunjukkan nilai heterosis negatif, hal ini juga menunjukkan bahwa kontribusi gen indukan betina lebih mendominasi dibandingkan dengan indukan jantan RR yang mempunyai lebar capit lebih besar daripada AA. Betina huna biru menyebabkan pleotropik yaitu yang 

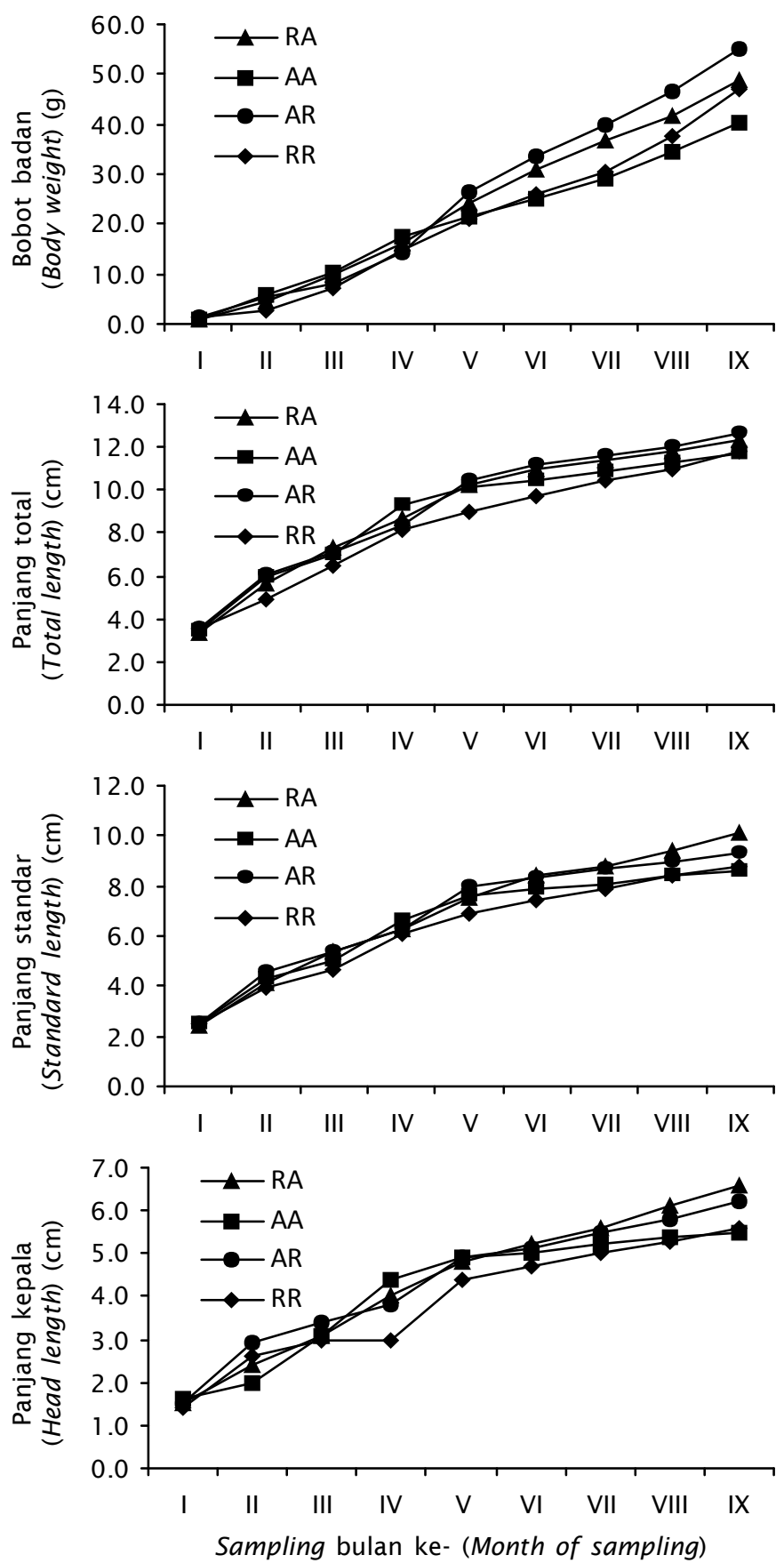

Gambar 1. Perkembangan bobot badan, panjang (total, standar, kepala) F1 hasil hibridisasi antara huna biru dengan huna capitmerah sampai umur 9 bulan

Figure 1. The growth rates of body weight, body length (total, standard, head) of Fl hybrid of blue crayfish and redclaw reared for 9 months 


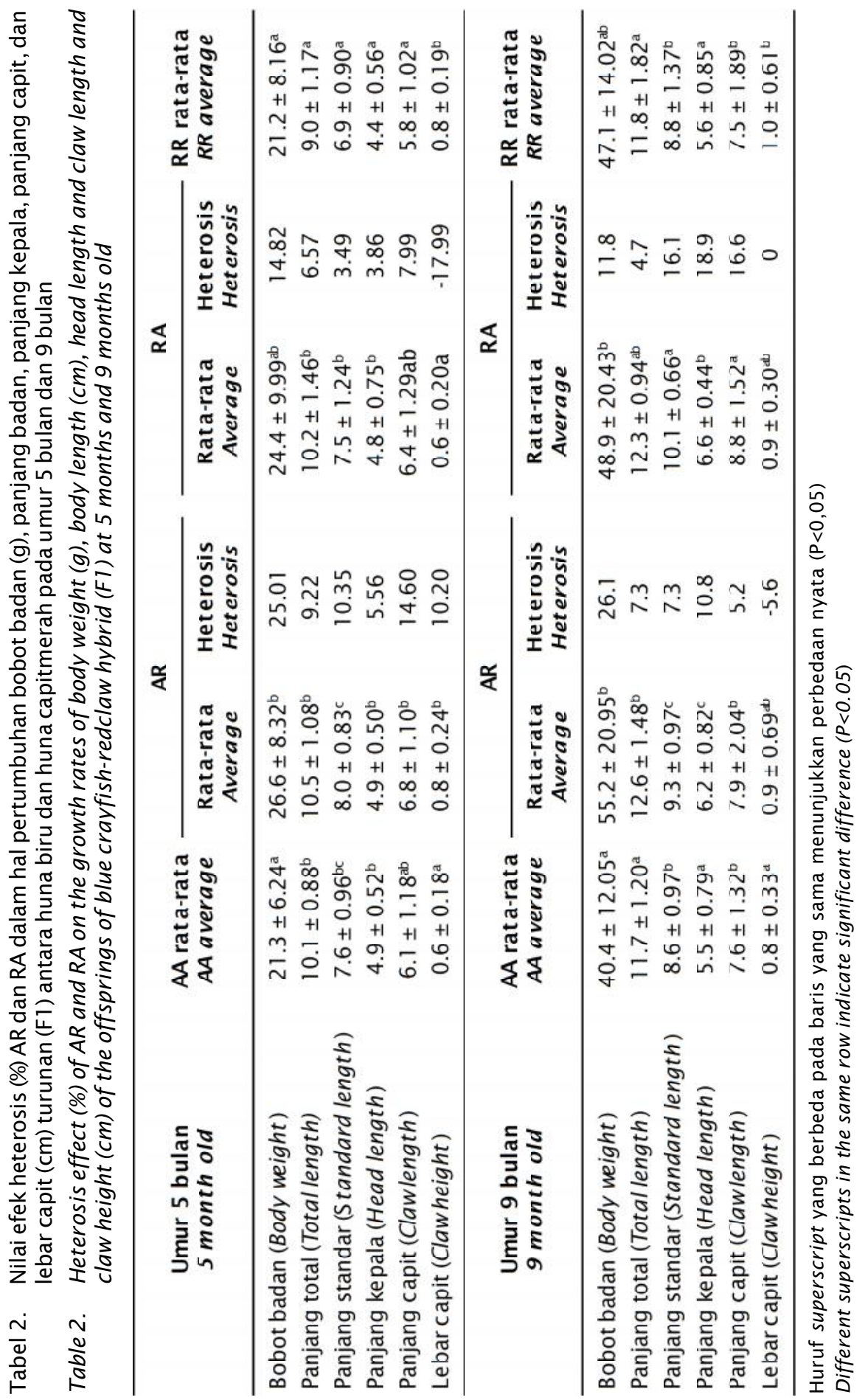




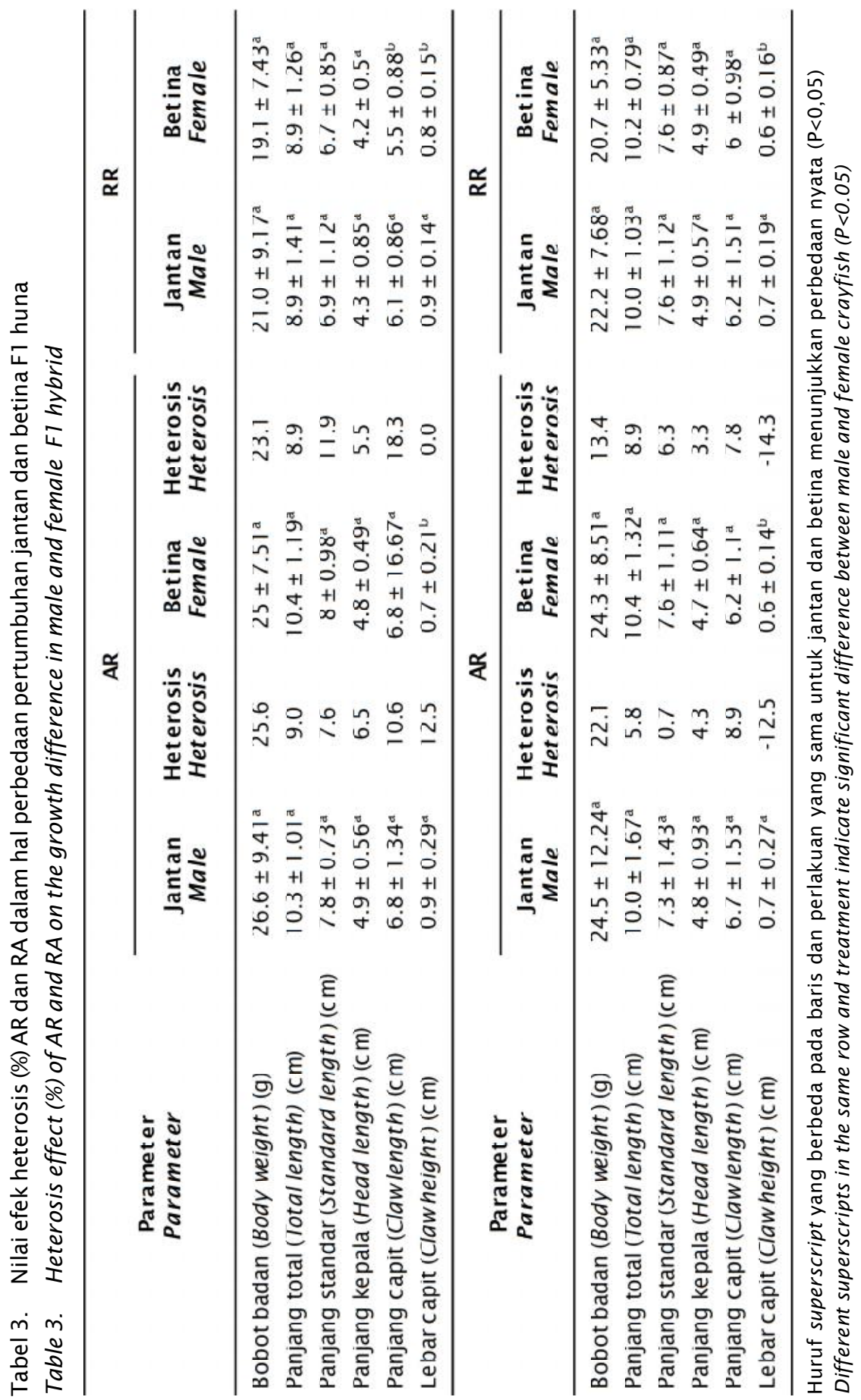


Tabel 4. Sintasan dan rasio kelamin jantan dan betina turunan (F1) hasil hibridisasi antara huna biru dengan huna capitmerah

Table 4. Survival rate and sex ratio of male and female progeny (F1) of blue crayfish-redclaw hybrid

\begin{tabular}{|c|c|c|c|c|}
\hline $\begin{array}{c}\text { Sintasan } \\
\text { Survival rate }\end{array}$ & $\begin{array}{c}\text { AA }(n=160) \\
32 \text { ekor }(20 \%)\end{array}$ & $\begin{array}{c}\text { AR }(n=240) \\
49 \text { ekor }(20.41 \%)\end{array}$ & $\begin{array}{c}\text { RA }(n=240) \\
55 \text { ekor }(22.92 \%)\end{array}$ & $\begin{array}{c}R R(n=240) \\
55 \text { ekor }(22.92 \%)\end{array}$ \\
\hline Jantan (Male) & 12 (37.5\%) & 23 (46.93\%) & $21(38.18 \%)$ & 30 (54.54\%) \\
\hline Betina (Female) & 20 (62.5\%) & 26 (53.07\%) & $34(61.82 \%)$ & 25 (45.46\%) \\
\hline
\end{tabular}

Keterangan: $\mathrm{n}=$ Jumlah populasi awal

Note: $n=$ Number of initial population

menyebabkan lebar capit menjadi kecil (negatif). Menurut Tim Cherax (2006), ukuran capit huna capitmerah lebih besar dibandingkan dengan huna biru, ukuran capit huna capitmerah (2-3 kali lebar tangkai capit). Bila ada dua gen saling berpengaruh secara berlawanan, maka kedua pengaruh tersebut dapat akan saling mengurangi. Sebaliknya apabila kedua gen saling mempengaruhi yang sama, maka semua pengaruhnya akan bersifat menambah. Heterosis adalah keunggulan beberapa sifat yang semula terdapat dalam bangsa yang berbeda disatukan melalui persilangan, heterosis akan timbul pada sifat yang banyak dikendalikan oleh gen nonaditive (Hardjosubroto, 2001).

Nilai efek heterosis huna yang jantan untuk bobot badan dan lebar capit menunjukkan yang jantan lebih tinggi daripada yang betina (Tabel 3).

Berdasarkan Tabel 3, dapat terlihat untuk semua parameter dalam perlakuan yang jantan relatif tidak berbeda nyata dengan yang betina kecuali panjang capit betina RR lebih kecil dan lebar capit untuk semua perlakuan yang jantan berbeda nyata dengan yang betina. Nilai heterosis untuk bobot badan dan lebar capit menunjukkan huna jantan lebih tinggi daripada betina, untuk panjang capit perlakuan AR betina mempunyai nilai heterosis tinggi dibandingkan dengan jantan. Beberapa jenis Cherax pertumbuhan jantan lebih cepat pada tahap dewasa daripada pada tahap awal. Pertumbuhan Cherax betina lebih lambat pada tahap dewasa karena banyaknya energi dibutuhkan untuk reproduksi. Namun secara keseluruhan parameter untuk semua perlakuan tidak berbeda nyata $(P>0,05)$ antara pertumbuhan jantan dan betina, kecuali lebar capit dan panjang capit, sesuai dengan pernyataan Merrick (1993) bahwa Cherax destructor pada kondisi yang terkontrol tidak menunjukkan perbedaan nyata antara laju pertumbuhan jantan dan betina. Rata-rata pertumbuhan Cherax quadricarinatus jantan $(0,31 \pm 0,41 \mathrm{~g} /$ hari) menunjukkan signifikansi yang lebih tinggi daripada yang betina $(0,18 \pm$ 0,09 g/hari) (Manor et al., 2002).

Berdasarkan Tabel 4, terlihat bahwa sintasan untuk perlakuan hibrid dengan non hibrida sekitar 20\%-23\%. Rasio jenis kelamin jantan dengan betina AR hampir sama dengan RR mendekati perbandingan $1: 1$, sedangkan AA dan RA rasio betina lebih tinggi daripada yang jantan diduga dengan persilangan induk betina dari huna biru akan menghasilkan lebih banyak yang betina dibandingkan dengan yang jantan. Rasio jenis kelamin dan sintasan tidak mempunyai nilai heterosis signifikan, karena mempunyai nilai hampir sama dengan nonhibrida. Menurut Lawrence et al. (2006), persilangan antara jantan Cherax destructor albitus dengan betina Cherax destructor destructor menghasilkan $\mathrm{F} 1$ dengan sex ratio jantan:betina 1:1, sedangkan jantan Cherax destructor destructor yang disilangkan dengan betina Cherax destructor albitus menghasilkan $\mathrm{F} 13$ dari 4 famili dengan rasio 3 jantan : 1 betina, dan famili yang ke-4 dengan rasio $100 \%$ jantan. Rasio dari persilangan antara huna tidak berbeda nyata untuk tiap-tiap populasi menghasilkan Fl dengan perbandingan 1 betina: 1 jantan. Berdasarkan penelitian Akhmad et al. (2007) pemeliharaan huna capitmerah dengan bobot awal 4-7 g dan huna biru 2-4 g setelah dipelihara selama 3 bulan, sintasan untuk huna capitmerah sekitar $51 \%$, sedangkan huna biru $30 \%$. Rodgers et al. (2006) menyatakan hasil pengamatan terhadap huna capitmerah dengan padat penebaran 
4-6 ekor $/ \mathrm{m}^{2}$, pemeliharaan selama 145 hari sintasannya antara 41\%-52\%. Timbulnya sifat kanibalisme di samping faktor internal seperti faktor genetik, juga faktor eksternal seperti lingkungan.

\section{KESIMPULAN DAN SARAN}

\section{Kesimpulan}

1. Pertumbuhan turunan hibrida antara huna capitmerah dengan huna biru sampai 4 bulan relatif sama dengan non hibrida, pada umur 5 bulan pertumbuhan hibrida mulai terlihat lebih cepat dibandingkan dengan yang non hibrida.

2. Hibridisasi antara jantan huna biru dengan betina huna capit merah (AR) menghasilkan hibrida dengan efek heterosis 25\% pada pertumbuhan bobot badannya.

3. Hibridisasi antara jantan huna capitmerah dengan betina huna biru (RA) menghasilkan nilai sintasan yang lebih baik dibandingkan dengan AR.

\section{Saran}

- Pembudidaya huna dapat meningkatkan produksi benih sebarnya dengan memijahkan antara jantan huna biru dengan betina huna capitmerah.

- Program seleksi untuk huna biru dan huna capitmerah perlu dilakukan di Balai Riset Perikanan Budidaya Air Tawar.

\section{DAFTAR ACUAN}

Ahmad, T., Sofiarsih, L., \& Sutrisno. 2007. Budidaya terpadu Cherax quadricarinatus dan C. albertisii dengan padi dalam kolam tanah. J. Ris. Akuakultur, 2(2): 157-165.

Beaumont, A.R. \& Hoare, K. 2003. Biotechnology and genetics in fisheries and aquaculture. Blackwell Publishing Inc USA, p. 110-112.

Effendie, M.I. 1979. Metode biologi perikanan. Yayasan Dewi Sri Bogor, $112 \mathrm{hlm}$.

Falconer, D.S. 1996. Introduction to quantitative genetics. Longman Malaysia, p. 281 288 .
Hardjosubroto, W. 2001. Genetika hewan. Fakultas Peternakan Universitas Gadjah Mada, Yogyakarta, $235 \mathrm{hlm}$.

Hickling, C. 1968. Fish hybridization. Proc. of world symp. on warm water pond fish culture. FAO Fish Rep., 44: 1-10.

Kusmini, I.I. 2009. Inventarisasi budidaya Cherax di berbagai lokasi. Prosiding Seminar Nasional Kelautan V. "Dampak Krisis Global Pembangunan Kelautan \& Perikanan dalam Rangka Peningkatan Kesejahteraan Masyarakat Maritim". Universitas Hang Tuah. Surabaya, hIm. 293296.

Lawrence, C.S., Morrissy, N.M., Vercoe, P.E., \& Williams, I.H. 2006. Differences in growth rate, size at sexual maturity and sex ratio. Journal Freshwater Crayfish, 15: 24-35.

Lawrence, C.S. 2005. Yabby hibrid grouwth experiment. Fisheries Research Contract Report No. 11 , FRDC. Project no. 97/3/9.02. Aquaculture Development Fund of Western Australia. Project, p. 1-7.

Manor, R., Seger, R., Leibovitz, M.P., Aflalo, E.D., $\&$ Sagi, A. 2002. Intensification of redclaw crayfish Cherax quadricarinatus culture II. Growthout in a separate cell system. Aquaculture Engineering, 26: 263-276.

Merrick, J.R. 1993. Freshwater crayfish of New South Wales. Linnean Society of New South Wales Australia, $127 \mathrm{pp}$.

Rodgers, L.J., Saoud, P.I., \& Rouse, D.B. 2006. The effects of monosex culture and stocking density on survival, growth and yield of redclaw crayfish (Cherax quadricarinatus) in Earthen Ponds. Aquaculture, 259: 164-168.

Ryman, N. \& Utter, F. 1987. Population genetics and fishery management. Washington Sea Grant Program, London, p. 161-191.

Tave, D. 1993. Genetics for fish managers. The AVI Publ. Comp. Inc. NY. USA, 415 pp.

Tim Cherax. 2006. Permohonan pelepasan Cherax quadricarinatus (huna capitmerah). Departemen Kelautan dan Perikanan, Badan Riset Kelautan Perikanan, Balai Riset Perikanan Budidaya Air Tawar Bogor, 16 hlm. 